\title{
Tomographic anatomy of the vena cava and renal veins: features relevant to vena cava filter placement
}

\author{
Anatomia tomográfica da veia cava e das veias renais: aspectos relevantes \\ para implante de filtro de veia cava
}

\author{
Thiago Melo do Espírito Santo', Fernando Bacalhau', Adilson Ferraz Paschôa', \\ Bonno van Bellen', Igor Austin², Douglas Raci²
}

\begin{abstract}
Background: There is a growing demand for invasive procedures involving the inferior vena cava, in particular for placement of vena cava filters. It is not always easy to identify the more distal renal vein with cavography, for safe release of filters. Objectives: To determine parameters for the relationships between the renal veins and the infrarenal vena cava and their corresponding vertebral bodies, their relationships with biotype and the occurrence of anatomic variations, the relationships between vertebral bodies and the bifurcation of the common iliac veins and the distance from this bifurcation to the outflow of the more distal renal vein, with reference to placement of vena cava filters. Methods: A total of 150 abdominal computed tomography scans conducted from October to November 2011 were analyzed and classified according to the biotype exhibited (using Charpy's angle). Scans were performed at MEDIMAGEM and analyzed at the Integrated Vascular Surgery Service, both part of Hospital da Beneficência Portuguesa in São Paulo, Brazil. Results: In 127 of the 150 scans analyzed (84.66\%), the more distal renal vein emerged between the first lumbar intervertebral space (L1-L2) and the body of L2, irrespective of patient biotype. Just 23 patients (15.33\%) exhibited a more distal renal vein with outflow below the body of $L 2$, i.e. in the projection of the space between $L 2$ and $\mathrm{L} 3$. Conclusions: The radiological correlation between the confluence of the more distal renal vein and vertebral bodies exhibits little variation, irrespective of the biotype of the patient.
\end{abstract}

Keywords: renal veins; inferior vena cava; lumbar vertebrae; anatomy; radiology; biotypes.

\begin{abstract}
Resumo
Contexto: Há uma demanda crescente por procedimentos invasivos que abordam a veia cava inferior, especialmente o implante de filtros de veia cava. A identificação da veia renal mais caudal para a liberação segura do filtro nem sempre é fácil durante a cavografia. Objetivos: Estabelecer parâmetros da relação das veias renais e da cava infrarrenal com o corpo vertebral correspondente, sua relação com a biotipologia, presença de variações anatômicas, relação dos corpos vertebrais com a bifurcação das veias ilíacas comuns para a veia cava e distância desta bifurcação até a desembocadura da veia renal mais caudal, visando à implantação de filtro de veia cava. Métodos: Foram analisadas 150 tomografias computadorizadas de abdome no período entre outubro e novembro de 2011, tendo sido agrupadas de acordo com o biotipo apresentado (ângulo de Charpy). As tomografias forem realizadas na MEDIMAGEM e analisadas no Serviço de Cirurgia Vascular Integrada, ambas da Beneficência Portuguesa de São Paulo. Resultados: Dos 150 exames analisados, 127 (84,66\%) apresentaram a emergência da veia renal mais caudal desde a projeção do primeiro espaço intervertebral lombar (L1-L2) até o corpo de L2, independentemente do biotipo do paciente. Somente 23 pacientes (15,33\%) apresentaram a desembocadura da veia renal mais caudal abaixo do corpo de L2, ou seja, na projeção do espaço entre L2 e L3. Conclusões: A correlação radiológica da confluência da veia renal mais distal em relação aos corpos vertebrais apresenta pouca variação, independentemente do biotipo do paciente.
\end{abstract}

Palavras-chave: veias renais; veia cava inferior; vértebras lombares; anatomia; radiologia; biotipologia.

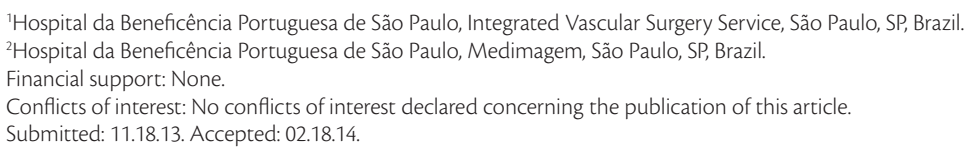




\section{INTRODUCTION}

Access to central vessels is most often employed in the territory of the superior vena cava and is predominantly used for placement of both short and long-term catheters. The navigability of the territory of the inferior vena cava has been most consistently explored for embolization procedures or cases in which there is a need to interrupt de vena cava. ${ }^{1}$

Placement of filters for partial interruption of the inferior vena cava was described by Mobin-Uddin in $1967,{ }^{1,2}$ with the aim of reducing the risk of pulmonary thromboembolism. The initial versions of these devices were more thrombogenic, but these were replaced with safer designs available in a variety of shapes and diameters to better fit the vessel's anatomy. It is recommended that the filter be released below the confluence of the renal veins because suprarenal placement can lead to renal vein thrombosis, with considerable impairment of renal function. ${ }^{3}$

Additionally, care should be taken to avoid or reduce the severity of nephropathy induced by the iodinated contrast. If a patient exhibits a glomerular filtration rate below $60 \mathrm{~mL} / \mathrm{min} / \mathrm{kg}$, no more than $100 \mathrm{~mL}$ of contrast should be used during the procedure, ${ }^{4}$ a precaution that is very often overlooked in practice.

On the basis of accumulated experience, radioscopic identification of the renal veins and the vena cava is recommended to ensure safe release of the filter. However, radioscopic identification is not always easy and may require high quantities of contrast, which increases morbidity related to the procedure. $^{5}$

Curiously, compendia on topographical and radiological anatomy do not define the relationships between the renal veins and the vertebral bodies, which is particularly relevant with relation to the more distal renal vein and must be respected at the time of placement of a vena cava filter.

Anatomic variations and malformations of the inferior vena cava can create invasive procedure that are only detected during the invasive procedures. ${ }^{1}$

Furthermore, there is also the risk of vena cava filter migration to the right atrium, a serious complication related to the difference in filter diameter and caval diameter. Duplicated caval veins should be identified since filter placement can be ineffective in these rare cases. ${ }^{6-8}$

The objective of this study was to establish parameters for the relationship between the renal veins and the infrarenal vena cava and their corresponding vertebral bodies, their relationships with biotypes and anatomic variations; the relationships between the vertebral bodies and the confluence of the common iliac veins into the vena cava and the distance between this bifurcation and the outflow of the more distal renal vein, with reference to placement of vena cava filters.

\section{MATERIALS AND METHODS}

Abdominal computed tomography (CT) scans from 150 individuals, taken in a variety of tomographs made by several manufacturers, and requested for investigation of a range of clinical conditions, were selected for analysis by simple sampling. Consecutive exams in which iodinated contrast was used were selected. Examinations had to have been conducted with $5 \mathrm{~mm}$ slices at $3 \mathrm{~mm}$ intervals and reconstructed as $1 \mathrm{~mm}$ slices at $1 \mathrm{~mm}$ intervals. Images were analyzed and processed on a workstation (Advantage Workstation 4.3-GE ${ }^{\circledR}$ ) by two radiologists. The only exclusion criteria for analysis of tomograms were age below 18 years and anatomic bone deformities, whether acquired or congenital, that prevented the biometric analysis based on classification according to Charpy's angle.

Patients were divided into three groups according to their biotypes, as measured during acquisition of tomographic images, brevilineal, normolineal or longilineal, using a classification proposed by Franco $^{9}$ and based on Charpy's angle (Figure 1), which in turn is the angle formed by the lowest two ribs with the base of the xiphoid appendix as its apex. A person is classified as normolineal if this angle is equal to 90 degrees; brevilineal when the angle is greater than 90 degrees, and longilineal when the angle is less than 90 degrees. $^{9}$

All calculations were performed on percentages only, since this study did not aim to provide statistical value but only analytical value. It is worth noting that the analysis is based on the anatomy exhibited by each individual.

The largest and smallest diameters of the vena cava diameter were measured and used to calculate its mean diameter. Any malformations involving the inferior vena cava and/or its tributaries were noted. The relationship between the outflow of the renal veins and the corresponding vertebral body and the relationship between the confluence of the common iliac veins and the corresponding vertebral body were recorded and the distance between this bifurcation and the outflow of the more distal renal vein was analyzed (Figure 2). 


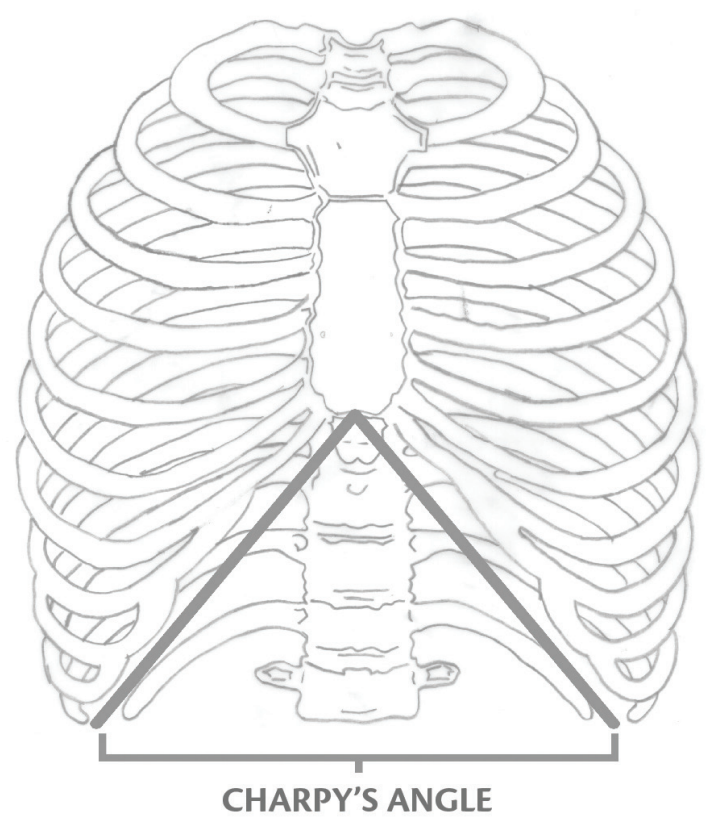

Figure 1. Schematic illustration of Charpy's angle.

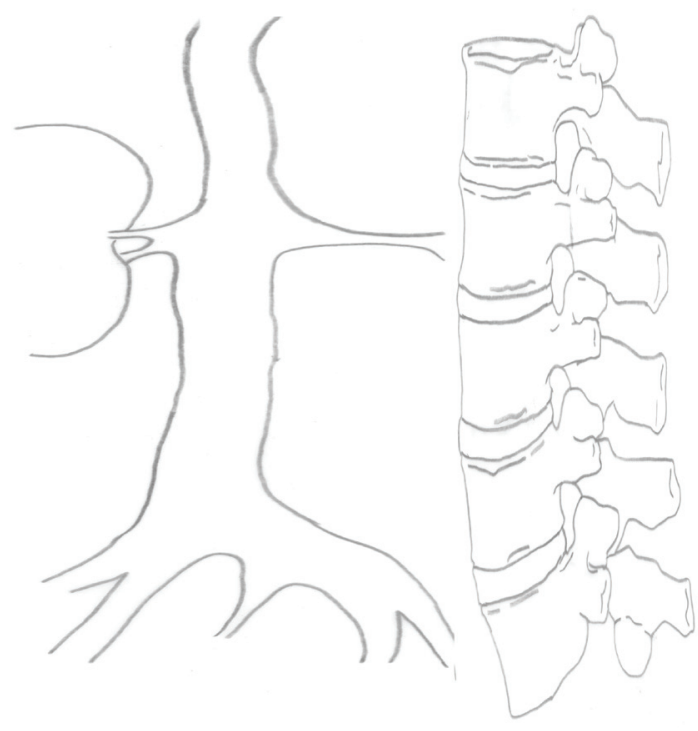

Figure 2. Schematic illustration of the relationship between the vena cava and renal veins and the vertebral bodies.

\section{RESULTS}

The mean age of patients was $61 \pm 4.4$ years, with a range of 19 to 87 . The sample comprised 96 men (64\%) and 54 women (36\%). There were 56 brevilineal patients (Charpy's angle greater than 90 degrees), accounting for $37 \%$ of the whole sample, and in 41 of these cases $(73 \%)$ the right renal vein was more distal, while in 15 cases $(27 \%)$ the left renal vein was more distal. The outflow of the more distal vein corresponded to the projection of intervertebral space L1- L2 in 14 cases (25\%); to the body of L2 in 19 cases (34\%), and to the L2-L3 intervertebral space in 23 cases $(41 \%)$. Mean infrarenal vena cava diameter was $2.03 \mathrm{~cm}$. The mean distance between the more distal renal vein and the confluence of the iliac veins was $8.81 \mathrm{~cm}$, with a range of $7.29 \mathrm{~cm}$ to $9.67 \mathrm{~cm}$. The confluence corresponded to the projection of L4 in 37 patients $(66 \%)$ and to the L4L5 intervertebral space in 19 cases (34\%).

The subset of normolineal individuals (Charpy's angle equal to 90 degrees), contained 63 cases (42\% of the total). The right renal vein was more distal in 54 cases $(86 \%)$ and the left in nine cases $(14 \%)$. The more distal vein corresponded to the projection of L1 in 14 cases (22\%); to the L1-L2 intervertebral space, in 31 cases (43\%), and to the vertebral body of L2 in 18 cases $(28 \%)$. The mean diameter of the inferior vena cava was $2.17 \mathrm{~cm}$. The mean distance between the more distal renal vein and the confluence of the iliac veins was $9.32 \mathrm{~cm}$, with a range of 7.91 $\mathrm{cm}$ to $10.2 \mathrm{~cm}$. The bifurcation corresponded to the projection of L4 in nine cases (14\%) and to the L3-L4 intervertebral space in 54 cases $(86 \%)$.

There were 31 cases $(20 \%$ of the total) in the subset of longilineal individuals (Charpy's angle less than 90 degrees). The right renal vein was more distal in 18 cases $(58 \%)$ and the left was more distal in 12 cases $(42 \%)$. The more distal renal vein was located at the projection of vertebral body L1 in seven cases (22\%), at the L1-L2 intervertebral space in 19 cases $(61 \%)$ and at the vertebral body of L2 in five cases $(16 \%)$. Mean infrarenal vena cava diameter was $2.21 \mathrm{~cm}$. The mean distance between the lower renal vein and the confluence of the iliac veins was $11.01 \mathrm{~cm}$, with a range of $9.7 \mathrm{~cm}$ to $12.4 \mathrm{~cm}$. The confluence was located at the projection of vertebral body L4 in six patients (19\%); at the projection of intervertebral space L4-L5 in 17 cases (55\%); at the vertebral body of L5 in eight patients $(26 \%)$, and between L4-L5 in 17 patients (55\%).

None of the images showed the more distal renal vein emerging distal to the body of the third lumbar vertebra.

Irrespective of biotype, in 127 of the 150 scans analyzed $(85 \%)$, the more distal renal vein was located in the space from the projection of the body of the first lumbar vertebra to the body of L2. In just 23 cases $(15 \%)$ it was located distal to the projection of the body of L2, i.e. in the projection of the L2- L3 intervertebral space.

With regard to anatomic variations, in two patients the inferior vena cava was duplicated below the renal 
veins $(1 \%)$; in three cases $(2 \%)$ there was a single kidney and in both there was also a single renal vein.

Four patients had an inferior vena cava with a diameter greater than $3 \mathrm{~cm} \mathrm{(3 \% ),} \mathrm{the} \mathrm{largest} \mathrm{of} \mathrm{which}$ was $5.3 \mathrm{~cm}$ in diameter. The mean vena cava diameter was $2.14 \mathrm{~cm}$.

\section{DISCUSSION}

Advances in endovascular venous procedures have increased the frequency of catheterization of the inferior vena cava system, in particular as a result of increasing use of vena cava filters. ${ }^{1,5,10}$

The inferior vena cava is the largest vein in the body and is responsible for return of blood from the lower limbs, from the majority of the abdominal wall and from the abdominopelvic viscera. It originates at the level of the fifth lumbar vertebra at the confluence of the common iliac veins, ascends along the psoas major muscle, to the right of the center plane, alongside the aorta. ${ }^{11}$ Notwithstanding the ubiquitous utilization of radiological methods for vascular diagnosis and treatment, text books on anatomy contribute very little to knowledge of the radiological anatomy of the vascular system in general. They do not describe the relationships between the outflow of the renal veins into the inferior vena cava and the vertebral bodies, which are important anatomic details when placing a vena cava filter, since the ideal site of placement is below the outflow.

There is a need to enrich the limited data available on radiological anatomy specifically focused on endovascular procedures in general and, in particular, on procedures involving placement of vena cava filters. There is no doubt that currently recommended techniques using radiological or ultrasonographic methods are very well-established, but these are not always available in a considerable proportion of hospital settings.

Ultrasonography requires a competent medical professional who is familiar with the steps involved in the procedure and the patient must offer appropriate clinical conditions, such as a favorable abdomen and any necessary intestinal preparation.

Radiological equipment is more widely available, but is very often unsuitable. Depending on technical conditions, filter placement can be complicated by low-quality equipments as much as by the clinical conditions of the patient. In all circumstances use of iodinated contrast should be kept to the minimum possible. However, the worse the radiological conditions, the larger the volumes of contrast employed.
In this context, basic knowledge of radiological anatomic references could minimize the need for using contrast, simply by predicting the ideal placement site while still in the radioscopic phase of the procedure.

The objectives of this study were specifically tailored to the reference points that are of fundamental importance to this procedure: the site of the more distal renal vein - whether this be the right renal vein or the left renal vein - in relation to the vertebral bodies; the diameter of the vena cava; the distance between the lower renal vein and the confluence of the iliac veins; and, finally, the influence that biotype has on these parameters.

The cases analyzed here were close to the national average in terms of biotypes. The most common constitutional type in the Brazilian population is normolineal, accounting for $39 \%$, followed by brevilineal, with $35 \%$, and longilineal, at $25 \% .^{12}$

Although anatomic variations of the inferior vena cava are uncommon and are seen as incidental findings in examinations and endovascular procedures, it must not be forgotten that they can cause problems during such procedures. This variant has an estimated prevalence of $0.5 \%{ }^{13,14}$ and just $6 \%$ of the anomalies of the inferior vena cava involve the infrarenal segment. There were two cases with anatomic variations $(1 \%)$ in the sample described here, which is a slightly higher proportion than that estimated in the literature. ${ }^{3}$

The formal guideline for the site of placement of vena cava filters is below the confluence of the renal veins,,$^{10}$ but, in certain situations, release in a suprarenal position is permitted, particularly in exceptional situations, such as the variants mentioned above or in cases of thrombosis of the inferior vena cava, thrombosis of renal veins and/or pregnancy. ${ }^{15}$

Cavography can be used during the invasive procedure to guide release of the device at the most appropriate site and to define the diameter of the vein to ensure the correct placement. However, despite cavography before the procedure being recommended, it is often not performed or, when it is conducted, there can often be problems with viewing and interpreting the images, whether because of poorly employed contrast, because an infusion pump is not available or because of difficulties visualizing the renal veins.

Habitually, filters can be safely opened in a vena cava from $18 \mathrm{~mm}$ to $30 \mathrm{~mm}$, with the exception being the 'Bird's Nest' type filters that can be employed in veins larger than $35 \mathrm{~mm} .{ }^{4,10,16}$ However, cavography 
does not always show the anatomic details needed and exposes patients to radiation and iodinated contrast. These concerns have motivated the search for alternative options that minimize these impacts, improving the quality of cavography by simplifying and guiding the procedure. Studies have shown that it is feasible to implant vena cava filters with guidance by abdominal ultrasonography, particularly for high-risk patients or those with significant renal dysfunction. $., 17,18$

The objective of this study was to identify simple parameters that could serve, in the majority of cases, as an aid to anatomical assessment to guide safe release of vena cava filters. Considering that the vertebral bodies can be seen during radioscopy, correlations between the anatomic positions of the renal veins and these structures could be used as a guide to the ideal site for release.

In the sample of patients described here, in 59\% of the brevilineal patients and $100 \%$ of the normolineal and longilineal patients, the more distal renal vein emerged above the body of the second lumbar vertebra. The more distal renal vein was distal of the body of L2, in the space between L2 and L3, in just 23 patients ( $15 \%$ of the whole sample), all members of the brevilineal subset.

The proportion of anatomic variations found in this study was greater than is described in the literature, ${ }^{7,14,19,20}$ since two patients had duplication of the inferior vena cava in the infrarenal region (1\% do total) and three patients ( $2 \%$ of the total) had a single renal vein feeding a single kidney.

\section{CONCLUSIONS}

The findings of this study are exclusively descriptive and do not provide a basis for concluding whether the anatomic parameter investigated could be used as a substitute for classical indications that are well-established in the literature, and which favor cavography and, more recently, intraoperative ultrasonography. Notwithstanding, knowledge of these relationships should simplify the daily routines of surgeons faced with problematic surgical fields, biotypical variants and, primarily, patients for whom administration of contrast for cavography is contraindicated or best minimized.

\section{REFERENCES}

1. Streiff $M B$. Vena caval filters: a comprehensive review. Blood. 2000;95(12):3669-77. PMid:10845895.
2. Pate JW, Melvin D, Cheek RC. A new form of vena caval interruption. Ann Surg. 1969;169(6):873-80. http://dx.doi. org/10.1097/00000658-196906000-00007. PMid:5770228

3. Van Ha TG. Complications of inferior vena caval filters. Semin Intervent Radiol. 2006;23(2):150-5. http://dx.doi. org/10.1055/s-2006-941445. PMid:21326758

4. Guimarães $M$, Uflacker R. Tratamento endovascular: fundamentos e técnicas básicas. In: Brito CJ, Duque AC, Merlo I, Silva RM Fonseca Filho VL, editors. Cirurgia vascular: cirurgia endovascular, angiologia. Rio de Janeiro: Revinter; 2008. p. 1195-224.

5. Stein PD, Kayali F, Olson RE. Twenty-one-year trends in the use of inferior vena cava filters. Arch Intern Med. 2004;164(14):1541-5. http://dx.doi.org/10.1001/archinte.164.14.1541. PMid:15277286

6. Moubarak G, Schleich JM, Daubert JC. Long-term efficacy of two vena cava filter implants for congenital duplicated inferior vena cava. Arch Cardiovasc Dis. 2009;102(1):77-8. http://dx.doi. org/10.1016/j.acvd.2008.06.009. PMid:19233113

7. Malgor RD, Sobreira ML, Boaventura PN, Moura R, Yoshida WB Implante de filtro em veia cava inferior dupla: relato de caso e revisão da literatura. J Vasc Bras. 2008;7(2):167-70. http://dx.doi. org/10.1590/S1677-54492008000200013.

8. Castro-Iglesias AM, Díaz-Bermúdez J, Gago-Ferreiro C, Noya-Castro A. [Double vena cava inferior]. Actas Urol Esp. 2010;34(9):823-4. http://dx.doi.org/10.1016/j.acuro.2010.02.041. PMid:20843466

9. Franco A Jr. Exame do tórax e pulmões. In: Benseñor IM, Atta JA Martins MA, editors. Semiologia clínica. São Paulo: Sarvier; 2002. p. 39-49.

10. Hoppe H. Optional vena cava filters: indications, management, and results. Dtsch Arztebl Int. 2009;106(24):395-402. PMid:19623306.

11. Gray $\mathrm{H}$. Veins of the lower extremity, abdomen and pelvis. In: Gray H, editor. Gray's anatomy. New York: Barnes \& Noble; 1995. p. 596-8.

12. Jaimovich CA, Mazzarone F, Navarro Parra JF, Pitanguy I. Semiologia da parede abdominal: seu valor no planejamento das abdominoplastias. Rev Soc Bras Cir Plast. 1999;14(3):21-50.

13. Chuang VP, Mena CE, Hoskins PA. Congenital anomalies of the inferior vena cava. Review of embryogenesis and presentation of a simplified classification. Br J Radiol. 1974;47(556):206-13. http:// dx.doi.org/10.1259/0007-1285-47-556-206. PMid:4824552

14. Eifert S, Villavicencio JL, Kao TC, Taute BM, Rich NM. Prevalence of deep venous anomalies in congenital vascular malformations of venous predominance. J Vasc Surg. 2000;31(3):462-71. http:// dx.doi.org/10.1067/mva.2000.101464. PMid:10709058

15. Ganguli S, Tham JC, Komlos F, Rabkin DJ. Fracture and migration of a suprarenal inferior vena cava filter in a pregnant patient. J Vasc Interv Radiol. 2006;17(10):1707-11. http://dx.doi.org/10.1097/01. RVI.0000236717.27681.09. PMid:17057016

16. Fonseca Filho VL, Oliveira FAC. Filtros de veia cava: tipos indicações, técnicas e resultados. In: Brito CJ, Duque AC, Merlo I, Silva RM, Fonseca Filho VL, editors. Cirurgia vascular: cirurgia endovascular, angiologia. Rio de Janeiro: Revinter; 2008. p. 1727-38.

17. Passman MA, Dattilo JB, Guzman RJ, Naslund TC. Bedside placement of inferior vena cava filters by using transabdominal duplex ultrasonography and intravascular ultrasound imaging. Vasc Surg. 2005;42(5):1027-32. PMid:16275468.

18. Neser RA, Capasso Filho M, Homa CMO. Implante de filtro de veia cava inferior guiado por ultra-som: relato de dois casos. J Vasc Bras. 2006;5(1):71-3. http://dx.doi.org/10.1590/ S1677-54492006000100014. 
19. Onzi RR, Costa LF, Angnes RF, et al. Malformação de veia cava inferior e trombose venosa profunda: fator de risco de trombose venosa em jovens. J Vasc Bras. 2007;6(2):186-9. http://dx.doi. org/10.1590/S1677-54492007000200016.

20. García-Fuster MJ, Forner MJ, Flor-Lorente B, Soler J, Campos S. Inferior vena cava malformations and deep venous thrombosis. Rev Esp Cardiol. 2006;59(2):171-5. PMid:16540040.
Correspondence Bonno van Bellen Rua Maestro Cardim, 925 CEP 01323-001 - São Paulo (SP), Brazil E-mail: bellen@apm.org.br

Author information TMES - Surgeon, former trainee at the Integrated Vascular Surgery Service at Hospital da Beneficência Portuguesa de São Paulo.

FB - Vascular surgeon, former trainee at the Integrated Vascular Surgery Service at Hospital da Beneficência Portuguesa de São Paulo AFP - Board certified in Vascular Surgery, PhD in Peripheral Vascular Disease from UNICAMP, Staff member of the Integrated Vascular Surgery Service, Hospital da Beneficência Portuguesa de São Paulo; Full member, SBACV.

BvB - Board certified in Vascular Surgery, Professor of Peripheral Vascular Disease at UNICAMP, Chief of the Integrated Vascular Surgery Service, Hospital da Beneficência Portuguesa de São Paulo, Full member of the SBACV and Colégio Brasileiro de Cirurgiões, Member, Society for Vascular Surgery. IA and DR- Board certified in Radiology, Radiologist at MEDIMAGEM, Hospital da Beneficência Portuguesa de São Paulo.

Author contributions Conception and design: AFP Analysis and interpretation: TMES, FB, IA, DR Data collection: TMES, FB, IA, DR Writing the article: AFP, TMES, BVB Critical revision of the article: $B \vee B$ Final approval of the article*: TMES, FB, AFP, BvB, IA, DR Statistical analysis: TMES, AFP Overall responsibility: BvB Obtained funding: None.

*All authors have read and approved of the final version of the article submitted to J Vasc Bras. 